\title{
Intercultural Dialogue: A Study of Patrick White's Voss and A Fringe of Leaves
}

\author{
Sukhendu Das \\ Dr Gour Mohan Roy College, Burdwan, India
}

\begin{abstract}
Patrick White's Voss and A Fringe of Leaves deal with the complex pattern of cultural negotiations. His representations of aboriginality have been viewed by many critics as essentialist and unprogressive. But this claim is not entirely tenable. In both of these novels White creatively fractures the essentialist notion of cultural identity. Dialogic interactions between two disparate cultures create interstitial space that profoundly unsettles the authority and authenticity of imperialist culture. The paper attempts to read these novels as complex textual sites where dialogic interchanges between two incompatible cultures have been rendered possible.
\end{abstract}

Keywords: Liminal space, Cultural negotiation, Dialogic interchange, Manichean polarization, Essentialism.

\section{Introduction}

David Richards's Masks of Difference explores the way indigenous peoples are represented in European culture. In dyads of binary opposition, Europeans are represented as having complex and unique individuality, while indigenous peoples are deemed to be harsh, brutish and immoral. In many travelogues, mostly written by the European explorers, native peoples were delineated in the savage Orcus aspect i.e. cannibal and rapist. European cultural artefacts, Richards observes, conform to this classical "grammar of representation" [1]. This politics of representations of aboriginality seems to inform White's Voss and A Fringe of Leaves. But a contrapuntal reading of these texts would inevitably open up fictive spaces that accommodate cross-cultural transactions, hybridized identity and catalytic exchanges.

Mr. Bonner's garden in Voss can be configured as a space that carries the values of imperialist culture. The white culture, like the horticultural science, has been transported to the alien Australian landscape. In his essay "The Desert and the Garden: The theme of completeness in Voss" Keith Garebian illustrates this issue:

The garden has long been a symbol of colonization, for its existence in a new world implies the importation into the new wilderness of civilizing, horticultural science. Unlike the desert, the garden is not primeval feature of the Australian landscape, for its organization and upkeep are the material evidence of colonial progress where life can take root and prosper in hitherto uncleared wastes... [2]

Domestication of nature has an imperialist vantage. Aboriginality, within this paradigm, is consigned to nature.

It is significant that in Mr Bonner's garden "the science of horticulture had failed to exorcise the spirit of the place. The wands and fronds of native things intruded still...." [3] So the garden of Mr Bonner can be read as a space where the indigenous culture and imperialist culture "meet, clash and grapple with each other, in a highly asymmetrical relations of domination and subordination..." [4]. The interaction between two disparate cultures can potentially disrupt the self-acclaimed authenticity of imperialist culture. The encroachment of native fronds (representing Indigenous Australia) upon the colonial space of Mr Bonner's garden is the symbolic manifestation of a suppressed fear that looms large in the consciousness of the colonizers [5].

In Mr Bonner's mansion Voss and Mr Bonner discuss the official journal of expedition. When $\mathrm{Mr}$ Bonner asks whether he has studied the map, Voss replies with sheer arrogance:

"... The map?" repeated the German. "I will first make it " [6].

Voss, therefore, attempts to textualise the spatial reality of Australia with the imperial gaze, which has been regarded as the long- standing feature of imperial advancement. So Mr Bonner's mansion accommodates imperial values.

Sue Rowley explores the politics of gendering exterior and interior spaces in the garden scene. She also points out the way women enter the nation-formation narratives in colonial literature:

In the late nineteenth century, this interior space frequently takes the form of domestic space. The gender ideology of 'separate spheres' ascribed domestic space to women. Concomitantly, exterior space was constructed in terms of the masculine domain; in bush mythology, the bush is masculine and exterior space. This delineation of interior and exterior space was often strident and insistent, suggesting a degree of anxiety and conflict about the terms under which women might enter the narratives of the formation of the nation... [7] The gender politics of the garden scene reflects the prevalent patriarchal colonial culture of that day as Patrick white states in a letter to Huebsch in 1956 that the novel "is based on that of records of the day" [8]. 
The rock art in the cave, Stephen Brock argues, sets up the binary between "the logos of the word in European culture" [9] and the mystical Indigenous culture:

The man was yielding himself up to the simplicity of the cave drawings. Henceforth all words must be deceitful, except those sanctioned by necessity, the handrail of language. [10]

Goldie associates oral culture of the indigenous peoples with otherness. Indigenous peoples "are illiterate, and thus beyond the dangerous supplement of writing". [11]

It is a cliché in exploration narrative to represent the Indigenous culture as 'resa tabula' ready to be wrought upon by white consciousness. The prime imperative of Voss's journey is to reinscribe white ideology on the virginal space of indigenous Australia. Such imperial project, however, gets thwarted as the indigenous culture resists the advancement of European Consciousness. Jackie executes Voss in order to "break the terrible magic that bound him remorselessly, endlessly, to the white men" [12]. The destruction of Voss's letters by Dugald resists the encroachment of western logo-centric culture in a prehistoric aboriginal world. Negotiation of two disparate cultures seems to be impossibility here.

The final state of Jackie's consciousness creates space for such cultural negotiations. Dugald successfully rejects white logo-centric culture and safely returns to the safe haven of aboriginal world. His position at the end of the novel is unproblematic. But Voss's words gain an entry into Jackie's heart and concomitantly produce an embryo consciousness. J.J Healy's observation is worth quoting in this connection:

Jackie carries with him, whether he likes it or not, the burden of a new consciousness. He has contracted this from his association with the visionary white man, who has sowed certain magic and an obtrusive possession into the autochthonous world of the Aborigine. [13]

This embryonic conscience works to disrupt the equilibrium of his unified self. His self gets fractured:

In normal circumstances, the isolation would gradually have been reduced by the many little measures that made life agreeable and possible: by following

The tracks of animals, by looking into scrub or logs, by looking for water or honey, by looking, always by looking. Temporarily, however, his eyes would not see clearly, and the loneliness was increased by these thoughts.

Terrible knives of thought, sharpened upon the knives of the sun were cutting to him. [14]

The "terrible knives of thought" seems to tear apart his world. It turns Jackie into a Frankenstein; he drives the "knives of thought", given to him by his master, "against his master" [15].

In the end Jackie straddles two disparate cultures and occupies an "in-between" space that unsettles binaries. Such interstitial spaces pave the way for cultural hybridity that prevents identities from Manichean polarizing.

In A Fringe of Leaves, the bush section arises the problematic of cultural negotiations. Ellen's captivity at the hands of the aborigines is a re-enactment of "her imprisonment at the hands of the Roxburghs" in the English world [16].

In her captivity at the bush she suffers brutalities and humiliations:

They anointed her body regularly with grease and charcoal, and plastered her cropped head with beeswax, and stuck it with tufts of down and feather as on the occasion when she was received into the tribe.[17]

In British culture this event is not entirely unprecedented: "it might have been old Mrs Roxburgh adding or subtracting some jewel or feather in preparation for a dinner or ball".[18] Significantly British culture finds its replica in the indigenous culture, albeit in a less refined manner. Finally she shakes off the veneer of western identity and "goes native" deliberately. She partakes of a cannibalistic rite that completes the process of "going native":

She had raised the bone, and was tearing at it with her teeth, Spasmodically swallowing by great gulps which her throat threatened to return. But did not. She flung the bone away only after it was cleaned, and followed slowly in the wake of her cannibal mentors. She was less disgusted in retrospect by what she had done, then awed by the fact that she had been move to do it. The exquisite innocence of the forest morning, its quite broken by a single flute-note endlessly repeated, tempted her to believe that she had partaken of a sacrament. But there remain what amounted to an abomination of human behavior, a headache, and the first signs of indigestion. In the light of Christian morality she must never think of the incident again. [19]

The passage carries the linguistic burden of Christian sacrament rite. Spiritually she gets united with the land.

While appropriating indigenous culture the painter Sidney Nolan replaced the pejorative "primitive other" with "the sacred other". [20]

Indigenous culture appeared to Nolan as spiritually rich. White seems to conform to Nolan's view. Ellen's cannibalistic act is not the marker of primitive culture. White culture also takes part in the selfsame ritual, albeit in a refined manner. Her cannibalistic sacrament arises the complex issue of cultural negotiations. Her sojourn among the aborigines goes on to prove that Apollonian white culture too carries the dark Dionysiac negative pole. Her cannibalistic act makes the claim to purity of culture untenable. Aboriginal culture can potentially disrupt the Apollonian certainty of white culture. Since she "goes native", she profoundly unsettles 
the authority and authenticity of imperialist culture. As she hovers between two incompatible cultures, her position reinforces the possibility of intercultural dialogue. She occupies a luminal space that dismantles Manichean polarizations.

In both Voss and A Fringe of Leaves, White creatively fractures historical stereotypes. Transgressing stereotypes, White's novels seem to advocate the notion of postmodernist identity that promotes the idea of decentred multiple identities in lieu of a centered, unified self. His novels can be configured as textual sites where dialogic interchanges between two disparate cultures have been rendered possible.

\section{References}

[1] David Richards, Masks of Difference: Cultural Representations in Literature, Anthropology and Art (Cambridge, Cambridge University Press, 1994).

[2] Keith Garebian, The Desert and the Garden: The Theme of Completeness in Voss, Modern Fiction Studies, 22(4), Winter 1976-77.

[3] Patrick White, Voss (Ringwood, Penguin Books, 1962).

[4] Bill Ashcroft, Gareth Griffiths and Helen Tiffin, Key Concepts in Post-colonial Studies (London, Routledge, London, 2001).

[5] Stephen Brock, A Travelling Colonial Architecture, doctoral diss., The Flinders University of South Australia, Australia, 2003.

[6] Patrick White, Voss (Ringwood, Penguin Books, 1962).

[7] Sue Rowley, The Journey's End: Women's Mobility and Confinement' Australian Cultural History, 10, $1991,69$.

[8] David Marr, Patrick White: A Life (Sydney, Random House, 1991).

[9] Stephen Brock, A Travelling Colonial Architecture, doctoral diss., The Flinders University of South Australia, Australia, 2003.

[10] Patrick White, Voss (Ringwood, Penguin Books, 1962).

[11] Terry Goldie, Fear and Temptation: The Image of the Indigene in Canada, Australia, and New Zealand Literature (McGill-Queen's University Press, London, 1989) p. 210.

[12] Patrick White, Voss (Ringwood, Penguin Books, 1962).

[13] J.J. Healy, Literature and the Aborigine in Australia (University of Queensland Press, 1989).

[14] Patrick White, Voss (Ringwood, Penguin Books, 1962).

[15] Stephen Brock, A Travelling Colonial Architecture, doctoral diss., The Flinders University of South Australia, Australia, 2003.

[16] Andrew Elfenbein, Narrating Australia: Competing Heroisms in A Fringe of Leaves, Commonwealth Novel in English, 6, 1993

[17] Patrick White, A Fringe of Leaves (London, Penguin Books, 1977).

[18] Ibid.

[19] Ibid.

[20] Kay Schaffer, In the Wake of First Contact (Cambridge, Cambridge University Press, 1998). 